\title{
A magasvérnyomás-betegség prevalenciája túlsúlyos és elhízott magyar gyermek- és serdülőkorú populációban
}

\author{
Jakab Andrea Emese dr. ${ }^{1}$ - Hidvégi Erzsébet Valéria dr. ${ }^{2}$ \\ Illyés Miklós dr. ${ }^{2}$. Cziráki Attila dr. ${ }^{2}$ - Kalmár Tibor dr. ${ }^{1}$ \\ Maróti Zoltán dr. ${ }^{1}$. Bereczki Csaba dr. ${ }^{1}$ \\ ${ }^{1}$ Szegedi Tudományegyetem, Szent-Györgyi Albert Klinikai Központ, \\ Gyermekgyógyászati Klinika és Gyermekegészségügyi Központ, Szeged \\ ${ }_{2}^{2}$ Pécsi Tudományegyetem, Általános Orvostudományi Kar, Klinikai Központ, Szívgyógyászati Klinika, Pécs
}

\begin{abstract}
Bevezetés: Napjainkban világszerte folyamatosan emelkedik a túlsúly és az elhízás előfordulási gyakorisága. Ez a jelenség nemcsak a felnőtt-, hanem a gyermek- és serdülőpopulációt is érinti. Ugyanakkor a túlsúly és az elhízás nem csupán kórállapotok, hanem számos egyéb megbetegedésnek, így emelkedett és magas vérnyomásnak a kialakulásához is vezethetnek.

Célkitüzés: Célunk az volt, hogy megvizsgáljuk a túlsúlyhoz és az elhízáshoz társult emelkedett és magas vérnyomás előfordulási gyakoriságát magyarországi 3-18 éves korú populációban.

Módszer: A vizsgálatba 2005 és 2018 között összesen 8624 (fiú = 4719) gyermeket és serdülőt vontunk be. Normál testsúlyú, túlsúlyos és elhízott csoportokat a testtömegindex alapján képeztünk. Az emelkedett ( $\geq 90-<95$ percentilis) és magas ( $\geq 95$ percentilis) vérnyomás diagnózisát részletes noninvazív kivizsgálás (laboratóriumi vizsgálat, hasi ultrahang, gyermekkardiológiai vizsgálat, 24 órás vérnyomás-monitorizálás) eredményeként állítottuk fel.

Eredmények: Vizsgálatunkban a túlsúly és az elhízás együttes előfordulási gyakorisága 23,5\% volt, ezen belül fiúknál 26,4\%, míg lányoknál 20\%. A túlsúlyos gyermekek és serdülők csoportjában az emelkedett vérnyomás prevalenciája 9,8\%, az elhízottaknál 4,6\% volt, míg a magas vérnyomás előfordulási gyakorisága 8,3\% (esélyhányados: 1,1; 95\% CI) volt a túlsúlyosak és 26,7\% (esélyhányados: 3,6; 95\% CI) az elhízottak között.

Következtetés: Tudomásunk szerint először közlünk magyarországi adatokat nagyszámú kortárs gyermek- és serdülőpopuláció esetében az emelkedett és magas vérnyomásnak a túlsúlyhoz és az elhízáshoz társuló előfordulási gyakoriságáról. A túlsúly és az elhízás a társult hypertoniával a szív-ér rendszeri betegségek kialakulása szempontjából fokozott kockázatot jelent. Éppen ezért kiemelkedően fontos a jól múködő primer prevenciós stratégiák kialakítása.

Orv Hetil. 2020; 161(4): 151-160.
\end{abstract}

Kulcsszavak: túlsúly, magas vérnyomás, gyermekek és serdülők, prevalencia, elhízottság

\section{Prevalence of hypertension in overweight and obese Hungarian children and adolescents}

Introduction: The prevalence of overweight and obesity is increasing worldwide, which affects not only adults, but children and adolescents as well. Moreover, this condition may lead to several comorbidities, such as elevated or even high blood pressure.

Aim: Aim of this study was to assess the prevalence of overweight- and obesity-related elevated and high blood pressure in a population aged 3-18 years in Hungary.

Method: Between 2005 and 2018, altogether 8624 (boys = 4719) individuals were enrolled to this study. Normal weight, overweight and obese groups were created on the basis of body mass index. The diagnosis of elevated (systolic and/or diastolic blood pressure is between 90th and 95th percentile) and high blood pressure (systolic and/or diastolic blood pressure is over 95th percentile) was based on detailed examination (laboratory tests, abdominal ultrasonography, paediatric cardiology and 24-hours ambulatory blood pressure monitoring). 
Results: In this study, the prevalence of overweight and obesity was $23.5 \%$ overall, $26.4 \%$ in boys and $20 \%$ in girls. The prevalence of elevated blood pressure was $9.8 \%$ in overweight patients, while it was $4.6 \%$ in the obese group. The prevalence of high blood pressure was $8.3 \%$ (odds ratio: $1.1 \%, 95 \% \mathrm{CI}$ ) among overweight subjects, while it was $26.7 \%$ (odds ratio: $3.6,95 \% \mathrm{CI}$ ) in the obese group.

Conclusion: To the best of our knowledge, this is the first Hungarian population-based study on the prevalence of overweight- and obesity-related elevated and high blood pressure assessed in a large contemporary cohort of children and adolescents. The cardiovascular risk is increased in this patient group. Hence, it is essential to set up a proper primary prevention strategy.

Keywords: overweight, hypertension, children and adolescents, prevalence, obesity

Jakab AE, Hidvégi EV, Illyés M, Cziráki A, Kalmár T, Maróti Z, Bereczki Cs. [Prevalence of hypertension in overweight and obese Hungarian children and adolescents]. Orv Hetil. 2020; 161(4): 151-160.

(Beérkezett: 2019. május 21.; elfogadva: 2019. június 24.)

\begin{abstract}
Rövidítések
$\mathrm{ABPM}=($ ambulatory blood pressure monitoring $) 24$ órás vérnyomás-monitorizálás; $\mathrm{BMI}=($ body mass index $)$ testtömegindex; $\mathrm{DBP}=($ diastolic blood pressure $)$ diasztolés vérnyomás; $\mathrm{EKG}=$ elektrokardiográfia FFA = (free fatty acids) szabad zsír savak; LDL = (low-density lipoprotein) alacsony sürüségü lipoprotein; MTA = Magyar Tudományos Akadémia; OR = (odds ratio) esélyhányados; PTE = Pécsi Tudományegyetem; RAAS $=$ (renin-angiotensin-aldosterone system $)$ renin-angiotenzin-aldoszteron rendszer; RKEB $=$ Regionális Kutatásetikai Bizottság; $\mathrm{RR}=$ respirációs ráta; $\mathrm{SBP}=($ systolic blood pressure) szisztolés vérnyomás; $\mathrm{WHO}=$ (World Health Organization) Egészségügyi Világszervezet
\end{abstract}

A túlsúly és az elhízás előfordulási gyakorisága az elmúlt évtizedekben folyamatosan emelkedett a gyermekek és a serdülők körében nemcsak a gazdaságilag fejlett, de a fejlődő országokban is [1]. 1975 és 2016 között globálisan az elhízás előfordulási gyakorisága 0,7\%-ról 5,6\%-ra emelkedett a 2-19 éves lányok esetében, míg a hasonló korú fiúknál ez a gyakoriság 0,9\%-ról 7,8\%-ra nőtt [2]. A túlsúly és az elhízás azonban nem pusztán esztétikai probléma, hanem számos, az egészségre káros következménye lehet már gyermekekben és serdülőkben is, így például korai érelmeszesedést, magasvérnyomás-betegséget okozhat, gyakran társul 2-es típusú cukorbetegséggel, következtében kialakulhat metabolikus szindróma, inzulinrezisztencia, asztma, obstruktív alvási apnoe, nem alkoholos zsírmáj, refluxbetegség [3].

Míg az 1970-80-as években az átlagos gyermek- és serdülőpopulációban az elsődleges magasvérnyomás-betegség előfordulási gyakoriságát 0,3-1,2\% között mérték $[4,5]$, addig napjainkban ezt globálisan $1,5-5 \%$ közöttire becsülik [6]. Több, ilyen irányú vizsgálat történt Európában is, így például Svájcban Chiolero és mtsai 12,3 éves korú populációban 2,2\%-nak [7], Lengyelországban Ostrowska-Nawarycz és mtsa 7-18 évesek között 4,9\%nak [8], míg hazánkban Katona és mtsai 15-18 évesek csoportjában 2,5\%-nak találta ezt a gyakoriságot [9].
Ismeretes, hogy túlsúlyos és elhízott gyermekek és serdülők körében az elsődleges magasvérnyomás-betegség sokkal gyakrabban fordul elő, mint normál testsúlyú társaiknál [10-16]. Lo és mtsai vizsgálatukban a túlsúly esetében 1, az elhízás esetében 3 súlyossági kategóriát képeztek, és azt mutatták ki, hogy a túlsúly 1,5-szeresre, míg az elhízás - az egyre súlyosabb kategóriákban 1,8-3,5-5,7-szeresre növeli az elsődleges magasvérnyomás-betegség kialakulásának kockázatát [16].

Az eddig e tárgykörben (a túlsúlyhoz és az elhízáshoz társuló hypertonia előfordulási gyakoriságáról) közölt tanulmányok módszertanával kapcsolatosan fontos kiemelni, hogy a hypertonia diagnózisa néhány esetben egyszeri $[10,14]$, más esetekben legfeljebb kétszer megismételt vérnyomásmérésen alapult $[11-13,15,16]$. Nem találtunk olyan jelentős esetszámú $(n>1000)$ populációs vizsgálatról beszámoló közleményt, melyben a magasvérnyomás-betegség fennállását részletes kivizsgálás és 24 órás vérnyomás-monitorizálás alapján állították volna fel.

Bár korábban már két magyar szerző is közölt adatokat elhízott gyermekek és serdülők körében mérhető magasvérnyomás-betegség előfordulási gyakoriságáról $[17,18]$, ezek a vizsgálatok nem populációs vizsgálatok voltak.

Ezért kutatásunk célja volt megvizsgálni a túlsúlyhoz és az elhízáshoz társuló magasvérnyomás-betegség prevalenciáját nagy, 3-18 éves korú populációban Szolnok városban oly módon, hogy a hypertonia diagnózisa valamennyi esetben részletes noninvazív kivizsgáláson és 24 órás vérnyomás-monitorizálás eredményén alapult.

\section{Módszer}

Vizsgálatunkban a túlsúly és az elhízás előfordulási gyakoriságának felméréséhez 2005. február 1. és 2018. március 31 . között gyüjtöttünk adatokat Szolnok város óvodáiban, általános és középiskoláiban. Összesen 8624 (n = 4719 fiú) egészséges, krónikus betegségben nem szenve- 
dő, gyógyszeres kezelésben nem részesülő gyermeket és serdülőt vontunk be a kutatásba. Valamennyi gyermek és serdülő csak egy alkalommal került vizsgálatra.

A vizsgálati alanyok antropometriai (testmagasság, testsúly) mérését Kern MGB 150K 100 típusú személymérleggel és MSF 200 típusú magasságmérő mechanikus rúddal (Kern \& Sohn GmbH, Balingen, Németország) végeztük el a szakma szabályai szerint [19]. Az aktuális vérnyomás méréséhez okkluzív-oszcillometriás müszert (Arteriográf, TensioMed Kft., Budapest) használtunk, melyet korábban noninvazív, invazív módon is validáltak $[20,21]$. A vérnyomás mérése az aktuális szakmai útmutatók ajánlásainak megfelelően történt [2224]. A normál testsúlyú, túlsúlyos és elhízott csoportokat a testtömegindex (body mass index, BMI) alapján képeztük, melyhez a Cole és mtsai által megadott, korra és nemre vonatkoztatott határértékeket használtuk [25].

Azoknál az alanyoknál, akiknél a korra és nemre vonatkoztatott, 90 percentilisnél magasabb szisztolés és/ vagy diasztolés vérnyomást mértünk, a helyszínen 10 perces időközökkel megismételtük a mérést még kétszer. Ha a helyszínen történt 3-szori mérés kapcsán felmerült az emelkedett (95>RR $\geq 90$ percentilis) vagy magas ( $R R \geq 95$ percentilis) vérnyomás [22-24, 26] gyanúja, akkor javasoltuk, hogy az érintett páciens vérnyomását iskolaorvosa, háziorvosa ellenőrizze. Ha az iskolaorvos, háziorvos ismételten magasabb vérnyomást mért, a pácienst magasvérnyomás-betegség irányában történő részletes kivizsgálás céljából gyermekkardiológiai járóbetegszakrendelésre irányította. A szakvizsgálat előtt áttekintő hasi ultrahang (különös tekintettel a vesék és a mellékvesék esetleges eltéréseire), valamint laboratóriumi vizsgálat (vérkép, ionok, vese- és májfunkció, vérzsírok, pajzsmirigy-stimuláló hormon) történt az esetleges szekunder hypertonia kizárása céljából. A gyermekkardiológiai vizsgálat során fizikális vizsgálat, 12 elvezetéses EKG, echokardiográfia (a hypertonia esetleges kardiológiai okának - coarctatio aortae - kizárására), valamint 24 órás vérnyomás-monitorizálás (ABPM) (CardioTens 01, CardioTens 02, Meditech Kft., Budapest) történt. Az ABPM során a karkörfogattól függően 4 különböző méretű mandzsettát használtunk a „nem domináns” karon [22, 24]. Az eredmények értékeléséhez az aktuálisan érvényes ABPM-referenciaértékeket használtuk [27, 28]. Magasvérnyomás-betegnek tekintettük azokat az egyéneket, akiknek az átlagos szisztolés és/vagy diasztolés vérnyo- mása a korra, nemre és testhosszra vonatkoztatott 95-ös percentilisérték feletti volt, és ennek hátterében szekunder ok nem igazolódott. A nemzetközi szakirodalomban közölt adatokkal való korrekt összehasonlítás céljából külön csoportban közöljük a 90 és 95 percentilisérték közötti ( $\geq 90$ és $<95$ ) szisztolés és/vagy diasztolés vérnyomást mutató egyének adatait, mely csoportot az „emelkedett vérnyomás” megnevezéssel láttuk el.

Az adatfeldolgozáshoz és a statisztikai próbák elvégzéséhez SPSS 22.0.0.0 programot (IBM Corporation, Armonk, NY, Amerikai Egyesült Államok) használtunk, amelynél a szignifikanciaszintet $\mathrm{p}<0,05$ értéken határoztuk meg.

A szülőket/törvényes képviselőket minden esetben szóban és írásban is tájékoztattuk a kutatás céljáról, az alanyok a beleegyező nyilatkozat szülők/törvényes képviselők által történt aláirása után kerültek be a kutatásba. A Pécsi Tudományegyetem Kutatásetikai Bizottsága kutatási tervünket áttekintette, és engedélyezte a vizsgálat elvégzését (PTE Centrum RKEB 2440. sz. [2005. 04. 01.]; hosszabbítás: 316-1992/KKl5/2011. [2011. 08. 02.]).

\section{Eredmények}

A túlsúly és az elhízás előfordulási gyakoriságát a 1 táblázatban mutatjuk be.

Vizsgálatunkban a fiúk 15,3\%-a volt túlsúlyos, 11,1\%-a elhízott, míg a lányok esetében 12,9\% volt a túlsúly, 7,1\% az elhízás előfordulási gyakorisága. A teljes populációt tekintve $14,3 \%$ a túlsúly, $9,2 \%$ az elhízás aránya. A túlsúly és az elhízás együttes előfordulási gyakorisága 23,5\% volt, és a fiúknál gyakrabban $(26,4 \%)$ alakult ki ez a kóros állapot, mint a lányoknál $(20,0 \%)(\mathrm{p}<0,05)$.

A normál testsúlyú, túlsúlyos és elhízott csoportok antropometriai (súly, magasság, BMI) és élettani (szisztolés és diasztolés vérnyomás, percenkénti szívfrekvencia) jellemzőit nem és életkor szerint vizsgáltuk. Az emelkedő életkor függvényében mindkét nemben, valamennyi súlycsoportban emelkedett a testsúly, a testmagasság, a BMI, a szisztolés és a diasztolés vérnyomás, míg a percenkénti szívfrekvencia csökkent. A testsúly, a BMI és a szisztolés vérnyomás szignifikánsan magasabb volt a túlsúlyos és elhízott fiúkban és lányokban majdnem valamennyi korcsoportban a normál súlyúakhoz képest, valamint az elhízott csoportban a túlsúlyos cso-

1. táblázat |A normál testsúlyú, túlsúlyos és elhízott egyének számának megoszlása nemenként a vizsgált populációban

\begin{tabular}{|c|c|c|c|c|c|c|}
\hline & Fiúk (n) & Arány (\%) & Lányok (n) & Arány (\%) & Összesen (n) & Arány (\%) \\
\hline Normál testsúlyú & 3474 & 73,6 & 3124 & 80,0 & 6598 & 76,5 \\
\hline Túlsúlyos & 725 & 15,3 & 506 & 12,9 & 1231 & 14,3 \\
\hline Elhízott & 520 & 11,1 & 275 & 7,1 & 795 & 9,2 \\
\hline Elhízott + túlsúlyos & 1245 & 26,4 & 781 & 20,0 & 2026 & 23,5 \\
\hline Mindösszesen & 4719 & & 3905 & & 8624 & \\
\hline
\end{tabular}


A

Normál súlyú fiúk

$$
n \text { (fö) }
$$

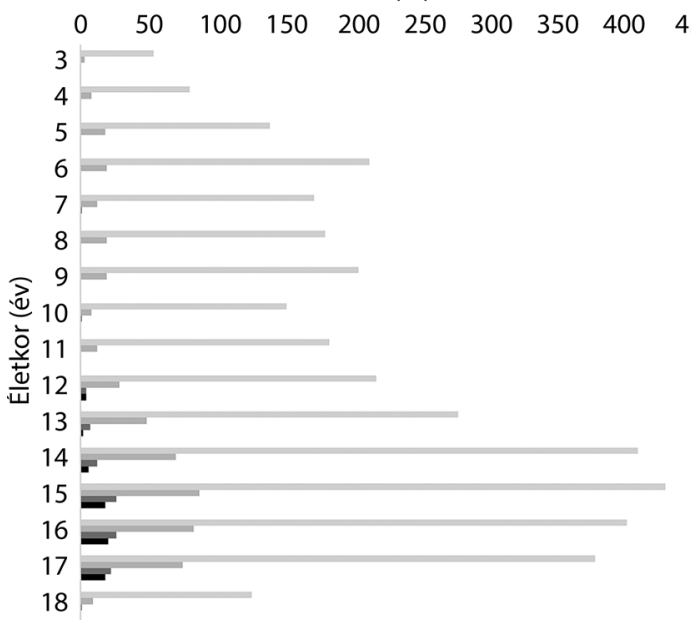

B

Túlsúlyos fiúk $\mathrm{n}$ (fő)

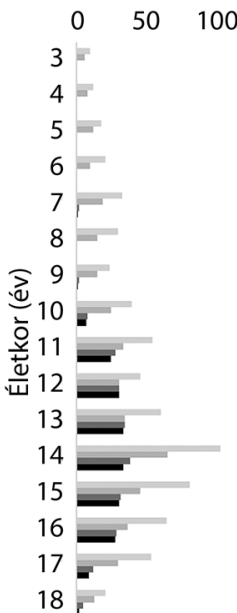

C

Elhízott fiúk

$\mathrm{n}$ (fö)

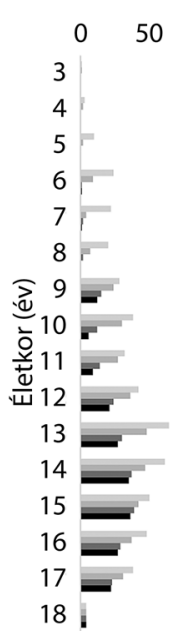

Normál súlyú lányok

$$
\text { n (fő) }
$$

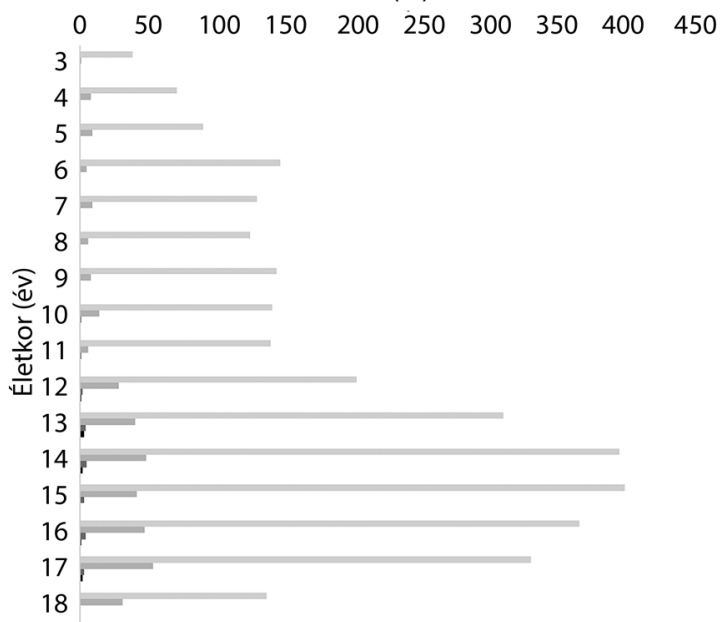

Túlsúlyos lányok $\mathrm{n}$ (fő)

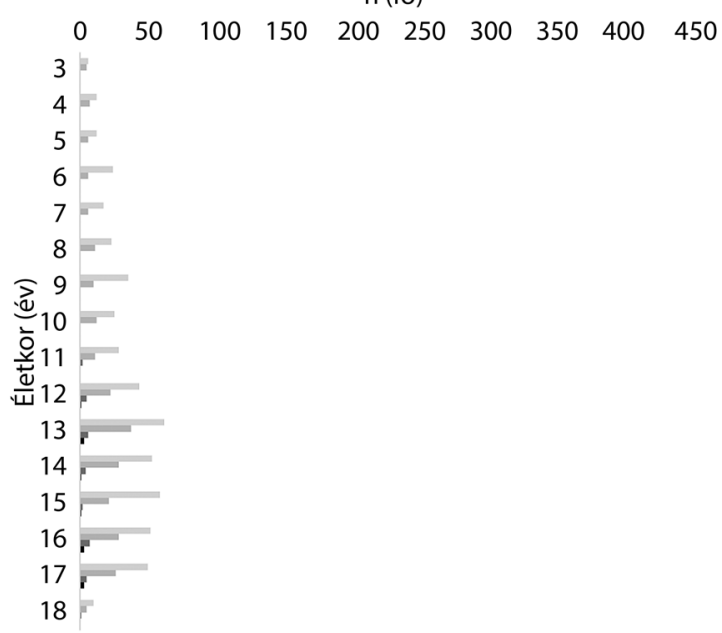

Elhízott lányok

n (fö)

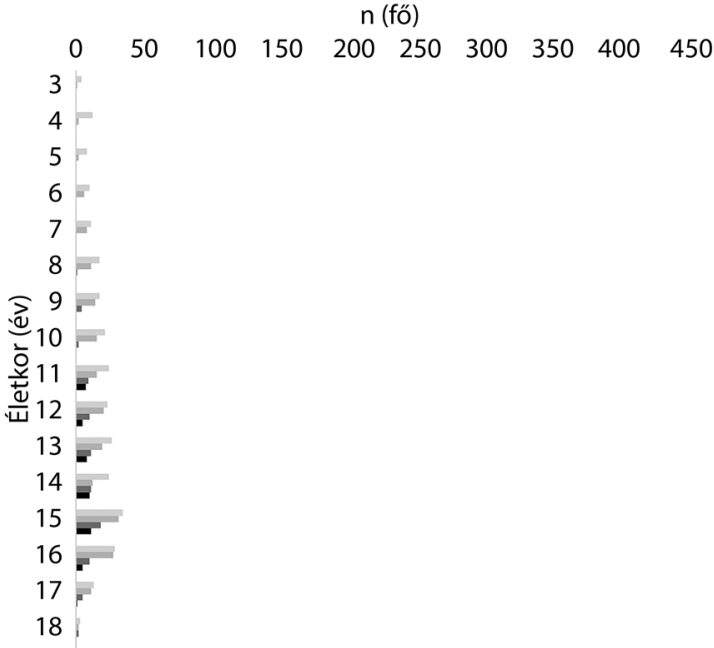

Összes páciens —Első méréskor emelkedett/magas RR ■Kivizsgálásra javasolt घABPM alapján emelkedett/magas RR

l. ábra $\quad$ A vizsgálat során mért vérnyomások (helyszíni, háziorvos/iskolaorvos által mért, ABPM) arányainak és a vérnyomásértékek megoszlásának grafikus ábrázolása normál testsúlyú (1/A), túlsúlyos (1/B) és elhízott (1/C) gyermekek és serdülók körében életkor szerint

$\mathrm{ABPM}=24$ órás vérnyomás-monitorizálás 


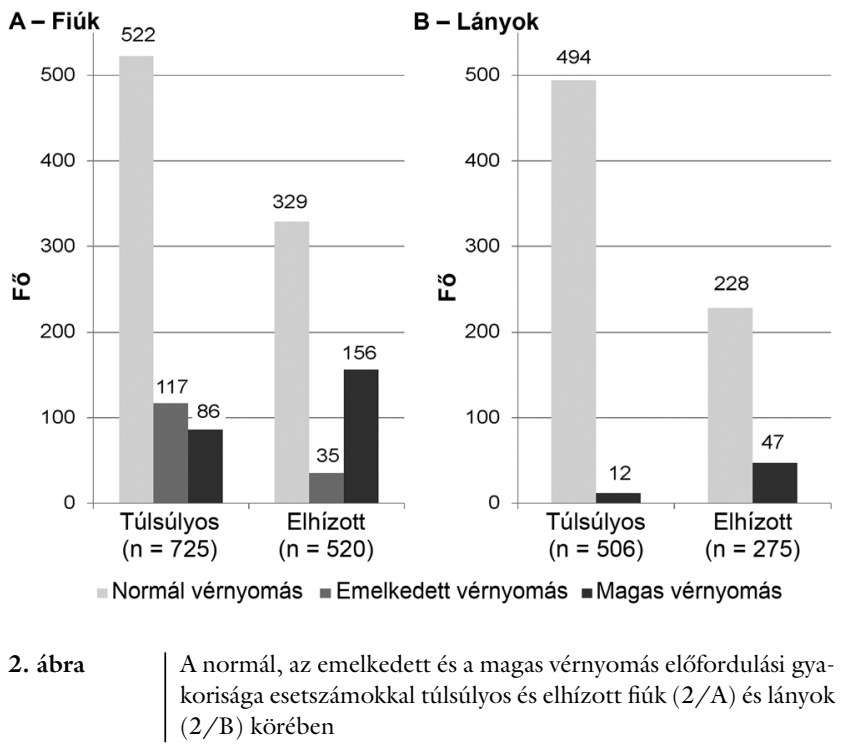

porthoz viszonyítva is, míg a testmagasság és a percenkénti szívfrekvencia statisztikailag kevésbé volt eltérő.

A vizsgálat során mért vérnyomásértékek megoszlását grafikus formában az 1 . ábra mutatja.

Az első, helyszíni vérnyomásmérést követően 1594 $(18,5 \%)$ esetben javasoltuk az ismételt mérést a házi- és/ vagy iskolaorvosok számára, ók 693 esetben $(43,5 \%)$ küldték a pácienseket kivizsgálásra, közülük 177-nek $(25,5 \%)$ volt emelkedett, míg 353-nak (50,9\%) magas a vérnyomása az ABPM alapján.

Miután a részletes kivizsgálást követően $25,5 \%$ volt az emelkedett és $50,9 \%$ a magas vérnyomású páciensek aránya, ebből arra következtethetünk, hogy kb. 23\% volt az ún. „fehérköpeny-” hypertonia előfordulási gyakorisága.

$\mathrm{Az}$ 1. ábráról leolvasható, hogy a vizsgált egyének a legnagyobb részben mindkét nemben a 12-17 évesek közül kerültek ki. Látható, hogy a túlsúlyos és az elhízott lányok csoportjában kevesebben vannak, mint az azonos

\section{A - Fiúk}
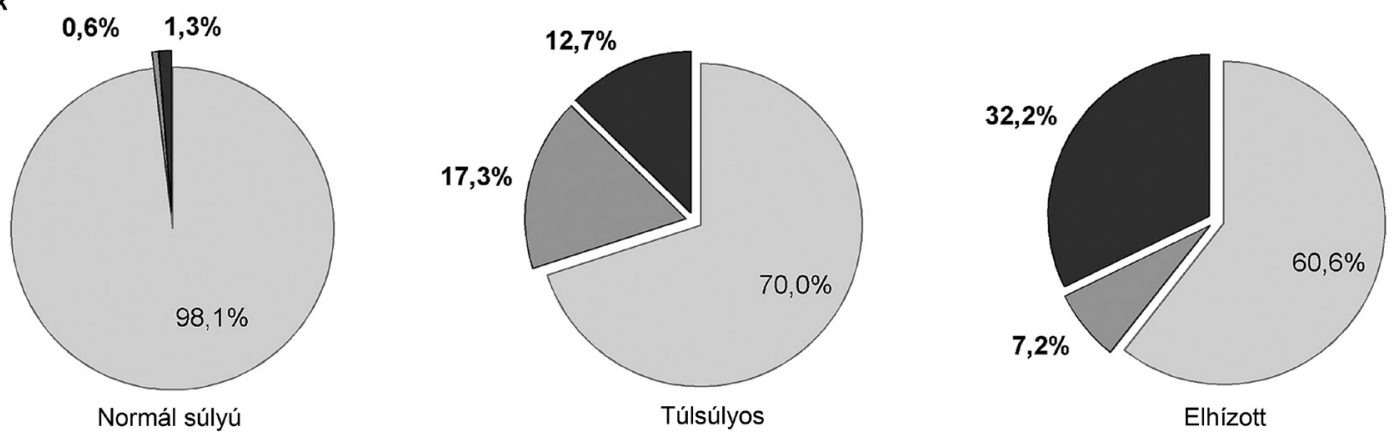

B - Lányok
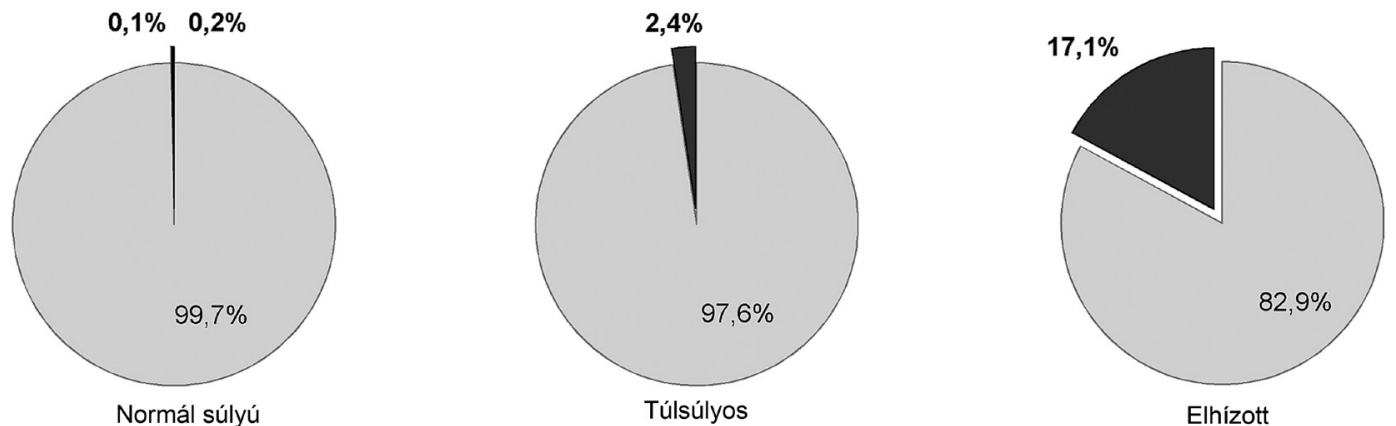

\section{C - Teljes populáció}
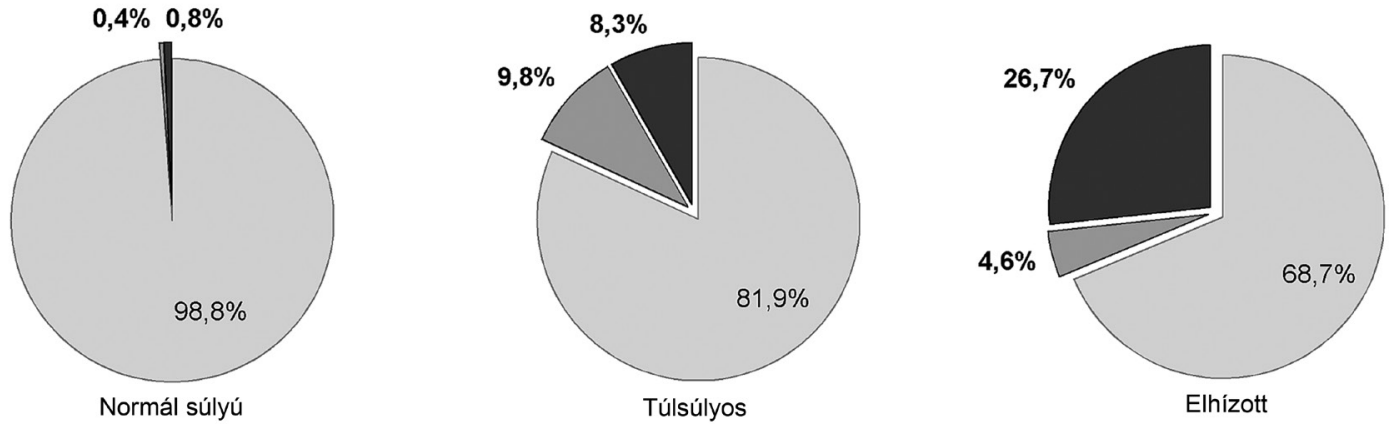

$\square$ Normál vérnyomás

口Emelkedett vérnyomás

- Magas vérnyomás

A normálsúlyhoz, a túlsúlyhoz és az elhízáshoz társuló normális, emelkedett és magas vérnyomás előfordulási gyakoriságának százalékos megoszlása fiúkban $(3 / \mathrm{A})$, lányokban $(3 / \mathrm{B})$ és a teljes populációban $(3 / \mathrm{C})$ 

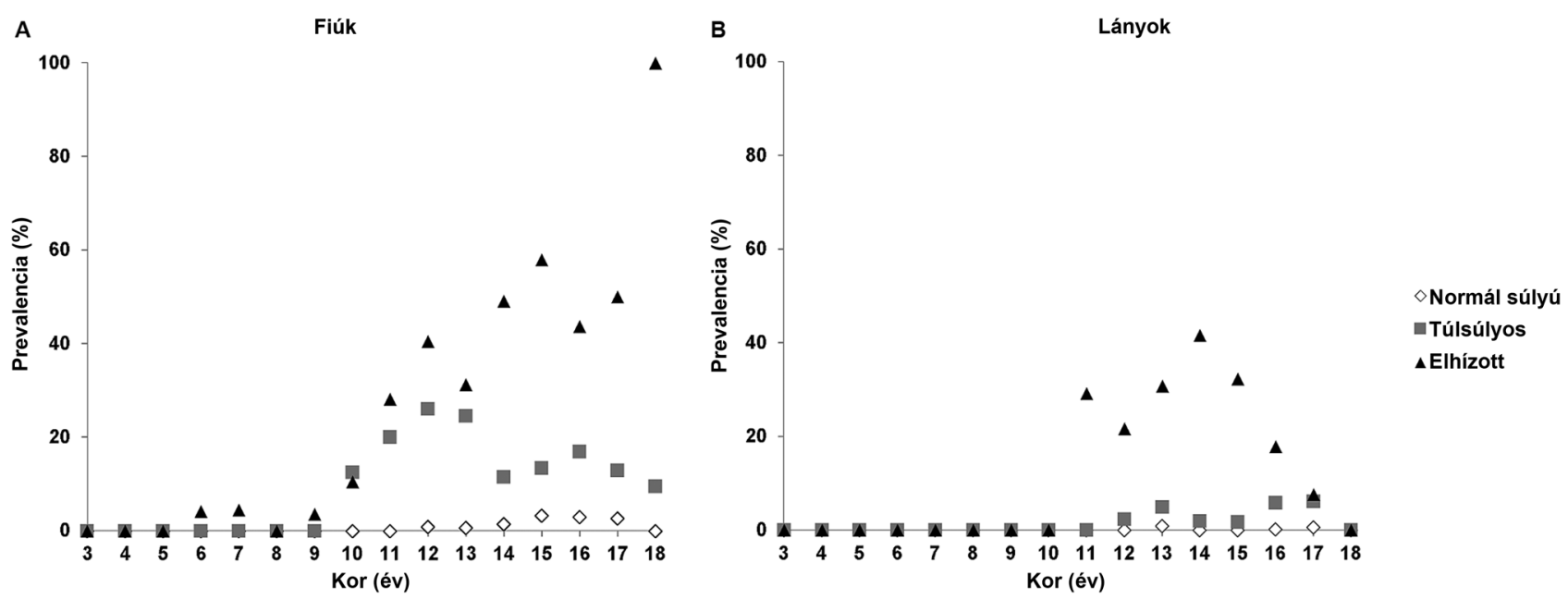

4. ábra

Az igazolt magasvérnyomás-betegség százalékos előfordulási gyakorisága a normál testsúlyú, a túlsúlyos és az elhízott fiúk (4/A) és lányok (4/B) körében életévenkénti megoszlásban

súlykategóriájú fiúkéban. A túlsúly fiúknál 13-16 éves, míg lányoknál 13-17 éves életkorban, míg az elhízás fiúknál 13-16 éves, lányoknál 13-16 éves korban volt a leggyakoribb.

A 2. ábra a normál, emelkedett és magas vérnyomású egyének esetszámok szerinti megoszlását mutatja a túlsúlyos és elhízott fiúk (2/A) és lányok $(2 / \mathrm{B})$ esetében. A 725 túlsúlyos fiú közül 86, az 520 elhízott fiú közül pedig 156 bizonyult hypertoniásnak, míg az 506 túlsúlyos lány közül 12, a 275 elhízott lány közül 47 volt magasvérnyomás-beteg is egyben. Az emelkedett vérnyomásúak száma a túlsúlyos fiúk között 117, míg az elhízott fiúk körében 35 volt. Lányok esetében a részletes kivizsgálást követően nem találtunk emelkedett vérnyomású pácienst.

A 3. ábra mutatja a normálsúlyhoz, a túlsúlyhoz és az elhízáshoz társuló normál, emelkedett és magas vérnyomás előfordulási gyakoriságának százalékos megoszlását. Az ábráról leolvasható, hogy a normál súlyú fiúk 1,3\%-a, a túlsúlyos fiúk 12,7\%-a, az elhízott fiúk 32,2\%-a (3/A), míg a normál súlyú lányok $0,2 \%$-a a túlsúlyos lányok 2,4\%-a, az elhízott lányok 17,1\%-a (3/B) bizonyult hypertoniásnak. Mind a túlsúlyos, mind az elhízott fiúk esetében szignifikánsan magasabb $(\mathrm{p}<0,0001)$ az előfor-

2. táblázat |A magasvérnyomás-prevalenciák összehasonlítása az egyes csoportok között (Student-féle t-próba)

\begin{tabular}{|c|c|c|c|c|c|c|c|c|c|}
\hline \multirow[t]{2}{*}{ Kor (év) } & \multicolumn{3}{|c|}{ Fiúk } & \multicolumn{3}{|c|}{ Lányok } & \multicolumn{3}{|c|}{ Fiúk vs. Lányok } \\
\hline & $\begin{array}{c}\text { Normál súlyúak } \\
\text { vs túlsúlyosak }\end{array}$ & $\begin{array}{l}\text { Normál súlyúak } \\
\text { vs elhízottak }\end{array}$ & $\begin{array}{c}\text { Túlsúlyosak } \\
\text { vs elhízottak }\end{array}$ & $\begin{array}{l}\text { Normál súlyúak } \\
\text { vs túlsúlyosak }\end{array}$ & $\begin{array}{l}\text { Normál súlyúak } \\
\text { vs elhízottak }\end{array}$ & $\begin{array}{c}\text { Túlsúlyosak } \\
\text { vs elhízottak }\end{array}$ & $\begin{array}{l}\text { Normál } \\
\text { súlyúak }\end{array}$ & Túlsúlyosak & Elhízottak \\
\hline 3 & - & - & - & - & - & - & - & - & - \\
\hline 4 & - & - & - & - & - & - & - & - & - \\
\hline 5 & - & - & - & - & - & - & - & - & - \\
\hline 6 & - & $\mathrm{p}<0,0001$ & $\mathrm{p}<0,0001$ & - & - & - & - & - & $\mathrm{p}<0,0001$ \\
\hline 7 & - & $\mathrm{p}<0,0001$ & $\mathrm{p}<0,0001$ & - & - & - & - & - & $\mathrm{p}<0,0001$ \\
\hline 8 & - & - & - & - & - & - & - & - & - \\
\hline 9 & - & $\mathrm{p}<0,0001$ & $\mathrm{p}<0,0001$ & - & - & - & - & - & $\mathrm{p}<0,0001$ \\
\hline 10 & $\mathrm{p}<0,0001$ & $\mathrm{p}<0,0001$ & $\mathrm{p}<0,0001$ & - & - & - & - & $\mathrm{p}<0,0001$ & $\mathrm{p}<0,0001$ \\
\hline 11 & $\mathrm{p}<0,0001$ & $\mathrm{p}<0,0001$ & $\mathrm{p}<0,0001$ & - & $\mathrm{p}<0,0001$ & $\mathrm{p}<0,0001$ & - & $\mathrm{p}<0,0001$ & NS \\
\hline 12 & $\mathrm{p}<0,0001$ & $\mathrm{p}<0,0001$ & $\mathrm{p}<0,0001$ & $\mathrm{p}<0,0001$ & $\mathrm{p}<0,0001$ & $\mathrm{p}<0,0001$ & $\mathrm{p}<0,0001$ & $\mathrm{p}<0,0001$ & $\mathrm{p}<0,0001$ \\
\hline 13 & $\mathrm{p}<0,0001$ & $\mathrm{p}<0,0001$ & $\mathrm{p}<0,0001$ & $\mathrm{p}<0,0001$ & $\mathrm{p}<0,0001$ & $\mathrm{p}<0,0001$ & NS & $\mathrm{p}<0,0001$ & NS \\
\hline 14 & $\mathrm{p}<0,0001$ & $\mathrm{p}<0,0001$ & $\mathrm{p}<0,0001$ & $\mathrm{p}<0,0001$ & $\mathrm{p}<0,0001$ & $\mathrm{p}<0,0001$ & $\mathrm{p}<0,0001$ & $\mathrm{p}<0,0001$ & $\mathrm{p}<0,0001$ \\
\hline 15 & $\mathrm{p}<0,0001$ & $\mathrm{p}<0,0001$ & $\mathrm{p}<0,0001$ & $\mathrm{p}<0,0001$ & $\mathrm{p}<0,0001$ & $\mathrm{p}<0,0001$ & $\mathrm{p}<0,0001$ & $\mathrm{p}<0,0001$ & $\mathrm{p}<0,0001$ \\
\hline 16 & $\mathrm{p}<0,0001$ & $\mathrm{p}<0,0001$ & $\mathrm{p}<0,0001$ & $\mathrm{p}<0,0001$ & $\mathrm{p}<0,0001$ & $\mathrm{p}<0,0001$ & $\mathrm{p}<0,0001$ & $\mathrm{p}<0,0001$ & $\mathrm{p}<0,0001$ \\
\hline 17 & $\mathrm{p}<0,0001$ & $\mathrm{p}<0,0001$ & $\mathrm{p}<0,0001$ & $\mathrm{p}<0,0001$ & $\mathrm{p}<0,0001$ & $\mathrm{p}<0,0001$ & $\mathrm{p}<0,0001$ & $\mathrm{p}<0,0001$ & $\mathrm{p}<0,0001$ \\
\hline 18 & $\mathrm{p}<0,0001$ & - & $\mathrm{p}<0,0001$ & - & - & - & - & $\mathrm{p}<0,0001$ & - \\
\hline
\end{tabular}

NS = non-szignifikáns 
dulási gyakoriság a lányokéhoz képest. Az egyes súlykategóriák teljes populációját (fiúk, lányok együtt) tekintve a túlsúlyos egyének 8,3\%-a, míg az elhízottak 26,7\%-a volt hypertoniás $(3 / \mathrm{C})$. Az emelkedett vérnyomású egyének aránya $0,6 \%$ a normál súlyú, 17,3\% a túlsúlyos, 7,2\% az elhízott fiúk között, ez az érték 0,1\% a normál súlyú lányok között, míg a túlsúlyos és az elhízott lányok között ilyet nem találtunk. A teljes populációban az emelkedett vérnyomású egyének aránya $0,4 \%$ volt a normál súlyúak, 9,8\% a túlsúlyosok és 4,6\% az elhízottak csoportjában.

A hypertonia prevalenciáját nemenkénti és életévenkénti bontásban grafikusan is bemutatjuk (4. ábra), mely grafikon számszerú adatait a 2. táblázat tartalmazza. Látható, hogy a normál súlyú fiúk esetében 14-17 éves, míg a normál súlyú lányok esetében 12-14 éves korban volt a legmagasabb a magas vérnyomás előfordulási gyakorisága. A túlsúlyos fiúknál 11-13 éves, lányoknál 16-17 éves, az elhízott fiúknál 14-18 éves, lányoknál 13-15 éves korban volt a legmagasabb a prevalencia. A statisztikai adatok azt mutatják, hogy 12-17 éves kor között szoros összefüggés van a növekvő testsúly és a magasvérnyomás-betegség prevalenciája között. Érdekes jelenség, hogy míg a normál súlyú és túlsúlyos fiúkban és lányokban az előfordulási gyakoriság csökkenő tendenciát mutat a 18. életév felé közeledve, addig az elhízott fiúk és lányok csoportjai között teljesen ellentétes tendencia látható: a fiúk esetében az továbbra is nő, lányoknál a 14. életévtől kezdve egyértelműen csökken.

Az általunk diagnosztizált magasvérnyomás-betegség hátterében 1 esetben kardiológiai (17 éves lány, coarctatio aortae), l esetben endokrinológiai (14 éves lány, pajzsmirigy-túlmúködés) ok állt. 34 esetben (27 fiú, 7 lány) javasoltunk részletes osztályos kivizsgálást a hasi ultrahangvizsgálat során észlelt veseelváltozások (ciszta, vesemedence-tágulat) miatt, mely vizsgálatok eredményéről 26 esetben kaptunk visszajelzést (a hypertonia hátterében nefrológiai ok nem igazolódott), míg 8 esetben nem ismerjük a végleges diagnózist.

\section{Megbeszélés}

Vizsgálatunk legfóbb eredményének azt tartjuk, hogy - legjobb tudomásunk szerint - először közlünk magyarországi adatokat nagy esetszámú kortárs gyermek- és serdülőpopuláció esetében túlsúlyhoz, elhízáshoz társuló elsődleges magasvérnyomás-betegség előfordulási gyakoriságáról. Kutatásunk egyedülálló a tekintetben is, hogy a hypertonia diagnózisát nem csupán az általános gyakorlat szerint elvégzett 3 egymást követő vérnyomásmérés alapján, hanem részletes noninvazív kivizsgálás és ABPM eredményeként állítottuk fel.

Vizsgálatunkban a magas vérnyomás előfordulási gyakorisága a teljes (fiú-lány) normál súlyú populációban $0,8 \%$, a túlsúlyosban $8,3 \%$, míg az elhízottak csoportjában $26,7 \%$ volt. Ez a gyakoriság statisztikailag magasabb volt mind a normál súlyú ( $1,3 \%$ vs $0,2 \%, \mathrm{p}<0,0001)$, mind a túlsúlyos $(12,7 \%$ vs $2,4 \%, \mathrm{p}<0,0001)$ és elhízott fiúk $(32,2 \%$ vs. $17,1 \%, p<0,0001)$ csoportjában a lányokéhoz képest.

A fiatalkori elsődleges magasvérnyomás-betegség jellemzően a férfiak betegsége, előfordulási gyakoriságát Cutler 5,5\%-nak találta 18-29 éves fehér férfiak, míg 0,8\%-nak hasonló korú nők körében [29]. Roberts vizsgálata szerint ez a különbség a nemek között 12 és 17 éves kor között manifesztálódik [30], aminek hátterében genetikai és biológiai faktorok állnak, és a serdülőkori megjelenést követően megmaradnak a felnőttkorban egészen a menopauzáig [31]. Ezt a jelenséget keringésélettanilag úgy magyarázhatjuk, hogy a fiúk nagyobb testmagasságot, testsúlyt érnek el a serdülés folyamata alatt, mint a lányok; ezt az intenzív anabolikus folyamatot a keringési rendszer megnövekedett keringő vértérfogattal szolgálja ki, mely az aktuális perifériás értérfogat és a megnövekedett keringő vértérfogat aránytalansága miatt emelkedett vagy magas vérnyomáshoz vezet. Ezen túl, miután a túlsúly és az elhízás előfordulási gyakorisága magasabb a fiúk körében, s a túlsúly és az elhízás számos egyéb kórélettani okból tovább emeli a vérnyomást, a hypertonia prevalenciája még inkább emelkedik a lányokéhoz képest.

A Pécsi Tudományegyetem Gyermekklinikájának munkatársai korábban már közöltek magyarországi adatokat az elhízáshoz társuló magas vérnyomás előfordulási gyakoriságáról $[17,18]$. Csábi és mtsai a metabolikus szív-ér rendszeri szindróma prevalenciáját mérték fel elhízott serdülőkben a klinika „elhízás” ambulanciájának betegei között. A vizsgált 103 elhízott fiú 39,8\%-a, míg a 77 elhízott lány 41,6\%-a volt hypertoniás ABPM alapján [17]. Török és mtsai a vérnyomás cirkadián ritmusát vizsgálták 73 elhízott, serdülőkorú páciensnél. A betegeket az ABPM diurnalis indexe alapján „dipper” (>10\%) és nem dipper $(<10 \%)$ csoportokba sorolták. A „dipperek" között 45,2\%, míg a nem dipperek csoportjában $83,9 \%$ volt a hypertonia gyakorisága [18]. Mindkét vizsgálatban jóval magasabbnak találták az elhízáshoz társuló hypertonia előfordulási gyakoriságát, mint a jelen tanulmányban munkacsoportunk. Ennek az lehet a magyarázata, hogy Csábi és Török nem átlagos populációt vizsgált, hanem egy speciális, az elhízás kivizsgálásával foglalkozó járóbeteg-szakrendelés betegeit.

Eredményeink összevetését a nemzetközi szakirodalomban közölt kiemelkedő jelentőségű tanulmányokkal a 3. táblázat foglalja össze. A kiválasztás fő szempontjai a következők voltak: legyen kortárs, azaz a vizsgálat ideje egyezzen meg a mi vizsgálatunk idejével (vagy rövidebb időtartam esetén essen bele), legyen nagy és/vagy legalább olyan esetszámú, mint saját vizsgálatunk, és közöljenek rizikóértéket, hogy ti. a túlsúly és az elhízás milyen mértékben emeli a magasvérnyomás-betegség kialakulásának kockázatát.

Lu és mtsai 2009-ben végeztek prospektív keresztmetszeti vizsgálatot Kínában (Sanghaj), melybe 78 114, 7-14 éves korú gyermeket és serdülőt vontak be [14]. 
3. táblázat | Eredményeink összehasonlítása két korábban publikált nagy populációs vizsgálat eredményeivel

\begin{tabular}{|c|c|c|c|c|}
\hline & $\begin{array}{c}\text { Normális vérnyomású } \\
\text { egyének } \\
\text { (<90 percentilis }) \\
\mathrm{n} / \%\end{array}$ & $\begin{array}{c}\text { Emelkedett vérnyomású } \\
\text { egyének } \\
(\geq 90->95 \text { percentilis }) \\
\text { n/\% }\end{array}$ & $\begin{array}{l}\text { Magas vérnyomású egyének } \\
\text { ( } \geq 95 \text { percentilis) } \\
\mathrm{n} / \%\end{array}$ & $\begin{array}{c}\text { Rizikó } \\
\text { Odds ratio (95\% CI) } \\
\text { (esélyhányados) }\end{array}$ \\
\hline Lu és mtsai; 2013 [14] & \multicolumn{4}{|c|}{ Kína, prospektív, keresztmetszeti, 2009, n = 78 114,7-14 év, higanyos vérnyomásmérés, $1 \times$ mérve } \\
\hline túlsúlyos $(\mathrm{n}=10252)$ & $8890 / 86,1$ & Nincs adat & $1362 / 13,9$ & 1,67 \\
\hline elhízott (n = 7 397) & $5797 / 78,4$ & Nincs adat & $1600 / 21,6$ & 2,17 \\
\hline Lo és mtsai; 2014 [16] & \multicolumn{4}{|c|}{ USA, retrospektív, keresztmetszeti, 2007-2010, n = 117 618, 6-17 év, oszcillometriás, $1 \times$ mérve, sze. $2 \times$ ismételve } \\
\hline túlsúlyos $(\mathrm{n}=11016)$ & $9454 / 65,6$ & $3402 / 23,6$ & $1562 / 10,8$ & $1,5(0,9-2,3)$ \\
\hline elhízott (n = 4582$)$ & $3348 / 51,6$ & $1906 / 29,4$ & $1234 / 19,0$ & $\begin{array}{l}1,8(1,1-3,0) \\
3,5(2,1-5,8) \\
5,7(3,6-8,9) \\
\end{array}$ \\
\hline Jakab és mtsai; 2020 & \multicolumn{4}{|c|}{ Magyarország, prospektív, keresztmetszeti, 2005-2018, n = 8 624, 3-18 év, okkluzív-oszcillometriás + ABPM } \\
\hline túlsúlyos $(\mathrm{n}=1231)$ & $1016 / 81,9$ & $117 / 9,8$ & $98 / 8,3$ & $1,1(0,8-1,3)$ \\
\hline elhízott (n = 795) & $557 / 68,7$ & $35 / 4,6$ & $203 / 26,7$ & $3,6(3,0-4,3)$ \\
\hline
\end{tabular}

$\mathrm{ABPM}=24$ órás vérnyomás-monitorizálás; $\mathrm{CI}=$ konfidenciaintervallum; USA = Amerikai Egyesült Államok

Az egyének vérnyomását 1 alkalommal mérték meg higanyos vérnyomásmérővel. Emelkedett vérnyomású egyénekról nem közöltek adatot; a magas vérnyomás előfordulási gyakoriságát 13,9\%-nak találták a túlsúlyos (OR: 1,67), míg 21,6\%-nak az elhízott (OR: 2,17) populációban.

Lo és mtsai az Egyesült Államokban (Észak-Kalifornia) elemezték 117 618, 6-17 éves korú egyén 2007 és 2010 között mért adatait retrospektív keresztmetszeti vizsgálatban, amelynek során a vérnyomást oszcillometriás módon mérték egy alkalommal, s a mérést szükség esetén (emelkedett szisztolés és/vagy diasztolés értéknél) még $2 \times$ megismételték [16]. Emelkedett vérnyomást mértek a túlsúlyos egyének 23,6\%-ában, az elhízottak 29,4\%ában, míg a magasvérnyomás-betegség előfordulási gyakorisága 10,8\% volt a túlsúlyos (OR: 1,5) és $19 \%$ az elhízott gyermekekben és serdülőkben (OR: 1,8-3,5-5,7).

Vizsgálatunkban a túlsúlyos egyének között 8,3\%-nak, az elhízottak között 26,7\%-nak találtuk a magasvérnyomás-betegség előfordulási gyakoriságát. Eredményeink jó egyezést mutatnak a fent idézett két jelentős vizsgálat eredményeivel, különösen az elhízáshoz társuló hypertonia előfordulási gyakoriságának tekintetében. Ez az arány $19 \%$ volt az amerikai [16] és 21,6\% a kínai [14] vizsgálatban. Ezen arányszámok a túlsúlyos egyének esetén a következók: 10,8\% az amerikai, 13,9\% a kínai kutatásban. Bár a 3 érintett vizsgálat eredményei nagyságrendjüket tekintve nem különböznek lényegesen, a kisfokú eltéréseket metodikai okkal is magyarázhatjuk. A kínai vizsgálatban saját, kínai gyerekekre és serdülőkre vonatkozó vérnyomás-referenciaértékeket [32], az amerikaiban a 2004-ben publikált, majd 2012-ben frissített amerikai ajánlás referenciaértékeit használták [22] a vérnyomás szerinti kategorizáláshoz, míg munkacsoportunk euró- pai referencia-adatbázisokat alkalmazott a vérnyomás szerinti csoportképzés során [27, 28].

Azt az érdekes eredményt, mely szerint a részletes kivizsgálás és a 24 órás vérnyomás-monitorizálás során nem találtunk emelkedett vérnyomást sem a túlsúlyos, sem az elhízott lányok között, úgy magyarázhatjuk, hogy egyrészt lányokban sokkal ritkábban fordul elő a magasvérnyomás-betegség a fiúkhoz képest a normál testsúlyúak között [29, 30], másrészt lényegesen kevesebb volt a túlsúlyos és elhízott lányok száma a fiúkhoz képest az általunk vizsgált populációban, s végül, még kevesebb volt a hypertonia előfordulási gyakorisága a túlsúlyos és elhízott lányok csoportjaiban. Ezek a tényezők együttesen vezethettek ehhez a jelenséghez, melyet ezzel együtt véletlennek tekintünk. Megjegyezzük, hogy a normál súlyú lányok csoportjában 3 esetben találtunk emelkedett vérnyomást.

A túlsúly és az elhízás nem pusztán a zsírszövet felszaporodását jelenti, hanem elindít egy olyan összetett anyagcserekaszkádot, mely végül a vérnyomás emelkedéséhez vezet [33]. Ez a folyamat fokozza a szív- és érrendszeri betegségek kialakulásának kockázatát a betegnél.

Ismeretes, hogy a zsírszövet nem pusztán inaktív kötőszövet, hanem endokrinológiai szempontból is kifejezetten aktív [34, 35], mely számos mediátorral ( „adipokinek") vesz részt az anyagcserében. Így például a zsírsejtekben termelődő, az adipokinek csoportjába tartozó leptin aktiválja a szimpatikus idegrendszert, ami a direkt vasoconstrictio és a renin-angiotenzin-aldoszteron (RAAS)-tengely aktiválásán keresztül emeli a vérnyomást [35]. Továbbá, az adipocyták maguk is termelnek RAAS-hormonokat, köztük aldoszteront. Kutatások igazolták, hogy elhízott egyénekben az aldoszteronszint emelkedett mind a szérumban, mind a vizeletben [36]. 
$\mathrm{Az}$ aldoszteron a vérnyomás szabályozásának kulcsszereplője, így hatással van a nátriumion homeosztázisára, következésképpen a keringő plazma térfogatára is [37]. Az elhízás következtében kialakuló egyéb, a cardiovascularis rizikót fokozó társbetegségek (dyslipidaemia, inzulinrezisztencia) is hozzájárulnak a fent részletezett metabolikus diszfunkció öngerjesztő köréhez. Ismeretes, hogy elhízásban a leptinrezisztencia és a hyperleptinaemia mellett az inzulinrezisztencia és a hyperinsulinaemia együttesen felelősek a fokozott szimpatikus aktiváció kialakulásában. Az emelkedett LDL-koleszterin-szint krónikus gyulladást képes indukálni, míg az inzulinrezisztencia gátolhatja a zsírszövet lipolízisét, ami emeli a szabad zsírsavak (free fatty acids, FFA) szintjét a szérumban [38]. Az emelkedett szabadzsírsav-szint fokozza az alfa-adrenerg-rendszer hatását, növelve ezzel az artériás tónust [33]. A fentiek alapján megállapíthatjuk, hogy az elhízáshoz társuló vérnyomás-emelkedés kialakulása öszszetett folyamat, melynek lényege a felszaporodott zsírsejtek anyagcserehatásai által aktivált szimpatikus idegrendszer regulációs zavara.

\section{Következtetés}

A túlsúlyhoz és az elhízáshoz társuló hypertonia kiemelt fontosságú népegészségügyi probléma világszerte, hiszen ezen állapotok egyre növekvő előfordulási gyakorisága egyúttal a magasvérnyomás-betegség incidenciáját is növelni fogja. Jelenleg a túlsúlyos és elhízott egyének szoros nyomon követése, a testsúlycsökkentés és az esetleges társbetegségek megfelelő kezelése az elsődleges feladatunk, de végső célként a sikeres elsődleges prevenciós stratégiák kidolgozását kell kitűznünk.

Anyagi támogatás: A közlemény megírása és a hozzá kapcsolódó kutatómunka az EFOP 3.6.1-16_5 támogatásában részesült.

Szerzői munkamegosztás: J. A. E. és H. E. V. végezte a kutatómunkát és a közlemény megírását B. Cs., I. M., C. A. útmutatásával. K. T. és M. Z. az adatok elemzésében és feldolgozásában segített. A cikk végleges változatát valamennyi szerző elolvasta és jóváhagyta.

Érdekeltségek: A szerzőknek nincsenek érdekeltségeik.

\section{Irodalom}

[1] Ng M, Fleming T, Robinson M, et al. Global, regional, and national prevalence of overweight and obesity in children and adults during 1980-2013: a systematic analysis for the Global Burden of Disease Study 2013. Lancet 2014; 384: 766-781.

[2] NCD Risk Factor Collaboration (NCD-RisC). Worldwide trends in body-mass index, underweight, overweight, and obesity from 1975 to 2016: a pooled analysis of 2416 population-based measurement studies in 128.9 million children, adolescents, and adults. Lancet 2017; 390: 2627-2642.
[3] Daniels SR. The consequences of childhood overweight and obesity. Future Child. 2006; 16: 47-67.

[4] Fixler DE, Laird WP, Fitzgerald V, et al. Hypertension screening in schools: results of the Dallas study. Pediatrics 1979; 63: 3236 .

[5] Sinaiko AR, Gomez-Marin O, Prineas RJ. Prevalence of 'significant' hypertension in junior high school-aged children: the Children and Adolescent Blood Pressure Program. J Pediatr. 1989; 114: 664-669.

[6] Falkner B. Recent clinical and translational advances in pediatric hypertension. Hypertension 2015; 65: 926-931.

[7] Chiolero A, Cachat F, Burnier M, et al. Prevalence of hypertension in schoolchildren based on repeated measurements and association with overweight. J Hypertens. 2007; 25: 2209-2217.

[8] Ostrowska-Nawarycz L, Nawarycz T. Prevalence of excessive body weight and high blood pressure in children and adolescents in the city of Łódź. Kardiol Pol. 2007; 65: 1079-1087. [Polish]

[9] Katona É, Zrínyi M, Lengyel S, et al. The prevalence of adolescent hypertension in Hungary - the Debrecen Hypertension Study. Blood Press 2011; 20: 134-139.

[10] Manzoli L, Ripari P, Rotolo S, et al. Prevalence of obesity, overweight and hypertension in children and adolescents from Abruzzo, Italy. Ann Ig. 2005; 17: 419-431. [Italian]

[11] Ostchega Y, Carroll M, Prineas RJ, et al. Trends of elevated blood pressure among children and adolescents: Data from the National Health and Nutrition Examination Survey 1988-2006. Am J Hypertens. 2009; 22: 59-67.

[12] Zhang YX, Wang SR. Monitoring of blood pressure in overweight and obese children in Shandong, China. Ann Hum Biol. 2011; 38: 603-607.

[13] Schwiebbe L, Talma H, Renders C, et al. High prevalence of hypertension in obese children in the Caribbean. Paediatr Int Child Health 2012; 32: 204-207.

[14] Lu X, Shi P, Luo C, et al. Prevalence of hypertension in overweight and obese children from a large school-based population in Shanghai, China. BMC Public Health 2013; 13: 24.

[15] Dyson PA, Anthony D, Fenton B, et al. High rates of child hypertension associated with obesity: a community survey in China, India and Mexico. Paediatr Int Child Health 2014; 34: 43-49.

[16] Lo JC, Chandra M, Sinaiko A, et al. Severe obesity in children: prevalence, persistence and relation to hypertension. Int J Pediatr Endocrinol. 2014; 2014: 3.

[17] Csábi Gy, Török K, Jeges S, et al. Presence of metabolic cardiovascular syndrome in obese children. Eur J Pediatr. 2000; 159: 91-94.

[18] Török K, Pálfi A, Szelényi Z, et al. Circadian variability of blood pressure in obese children. Nutr Metab Cardiovasc Dis. 2008; 18: 429-435.

[19] World Health Organization. Physical status: the use and interpretation of anthropometry. Report of a WHO Expert Committee. Technical Report Series No. 854. Geneva, 1995.

[20] Horváth IG, Németh A, Lenkey Z, et al. Invasive validation of a new oscillometric device (Arteriograph) for measuring augmentation index, central blood pressure and aortic pulse wave velocity. J Hypertens. 2010; 28: 2068-2075.

[21] Baulmann J, Schillings U, Rickert S, et al. A new oscillometric method for assessment of arterial stiffness: comparison with tonometric and piezo-electronic methods. J Hypertens. 2008; 26: 523-528.

[22] National High Blood Pressure Education Program Working Group on High Blood Pressure in Children and Adolescents. The fourth report on the diagnosis, evaluation, and treatment of high blood pressure in children and adolescents. Pediatrics 2004; 114(Suppl 2): 555-576.

[23] Flynn JT, Kaelber DC, Baker-Smith CM, et al. Clinical practice guideline for screening and management of high blood pressure in children and adolescents. Pediatrics 2017; 140: e20171904. doi: $10.1542 /$ peds.2017-1904. 
[24] Reusz Gy, Szabó L, Kis É. Guide for the treatment of hypertension in infants and childhood. [Útmutató a hypertonia csecsemőés gyermekkori ellátásához.] Gyermekgyógyászat 2019; 70: 109-120. [Hungarian]

[25] Cole TJ, Lobstein T. Extended international (IOTF) body mass index cut-offs for thinness, overweight and obesity. Pediatr Obes. 2012; 7: 284-294

[26] Schwandt P, Scholze JE, Bertsch T, et al. Blood pressure percentiles in 22,051 German children and adolescents: the PEP Family Heart Study. Am J Hypertens. 2015; 28: 672-679.

[27] Soergel M, Kirschstein M, Busch C, et al. Oscillometric twentyfour-hour ambulatory blood pressure values in healthy children and adolescents: a multicenter trial including 1141 subjects. J Pediatr. 1997; 130: 178-184.

[28] Lurbe E, Agabiti-Rosei E, Cruickshank JK, et al. 2016 European Society of Hypertension guidelines for the management of high blood pressure in children and adolescents. J Hypertens. 2016; 34: 1887-1920.

[29] Cutler JA, Sorlie PD, Wolz M, et al. Trends in hypertension prevalence, awareness, treatment, and control rates in United States adults between 1988-1994 and 1999-2004. Hypertension 2008; 52: 818-827.

[30] Roberts J. Blood pressure levels of persons 6-74 years. Book Blood pressure levels of persons 6-74 years (Editor ed.^eds.) Data from the National Health Survey edition.

[31] Everett B, Zajacova A. Gender differences in hypertension and hypertension awareness among young adults. Biodemography Soc Biol. 2015; 61: 1-17.
[32] Hou D, Hong C, TianYou W, et al. Study on the relationship of blood pressure with BMI, FMP and waist circumference among children and adolescents in Beijing. Chinese J Pract Pediatr. 2010; 25: 524-527.

[33] Leggio M, Lombardi M, Caldarone E, et al. The relationship between obesity and hypertension: an updated comprehensive overview on vicious twins. Hypertens Res. 2017; 40: 947-963.

[34] Kidambi S, Kotchen TA. Treatment of hypertension in obese patients. Am J Cardiovasc Drugs 2013; 13: 163-175.

[35] Brady TM. Obesity-related hypertension in children. Front Pediatr. 2017; 5: 197.

[36] Vecchiola A, Lagos CF, Carvajal CA, et al. Aldosterone production and signaling dysregulation in obesity. Curr Hypertens Rep. 2016; 18: 20.

[37] Schütten MT, Houben AJ, de Leeuw PW, et al. The link between adipose tissue renin-angiotensin-aldosterone system signaling and obesity-associated hypertension. Physiology (Bethesda) 2017; 32: 197-209.

[38] Mameli C, Zuccotti GV, Carnovale C, et al. An update on the assessment and management of metabolic syndrome, a growing medical emergency in paediatric populations. Pharmacol Res. 2017; 119: 99-117.

(Jakab Andrea Emese dr., Szeged, Korányi fasor 14-15., 6722 e-mail: jakab.andrea@med-u.szeged.hu; jakab.andrea0817@gmail.com)

\section{A rendezvények és kongresszusok híranyagának leadása}

a lap megjelenése előtt legalább 40 nappal lehetséges, a 6 hetes nyomdai átfutás miatt. Kérjük megrendelőink szíves megértését.

A híranyagokat a következő címre kérjük:

Orvosi Hetilap titkársága: edit.budai@akademiai.hu

Akadémiai Kiadó Zrt.

A cikk a Creative Commons Attribution 4.0 International License (https://creativecommons.org/licenses/by/4.0/) feltételei szerint publikált Open Access közlemény, melynek szellemében a cikk bármilyen médiumban szabadon felhasználható, megosztható és újraközölhető, feltéve, hogy az eredeti szerző és a közlés helye, illetve a CC License linkje és az esetlegesen végrehajtott módosítások feltüntetésre kerülnek. (SID_1) 